\title{
Manajemen Stres Berbasis Teknik HeartMath untuk Mengurangi Stres dan Mengelola Emosi pada Caregiver Pasien Penyakit Kronis
}

\author{
Tiara Diah Sosialita ${ }^{1}$ Hamidah $^{2}$ \\ 1,2 Fakultas Psikologi Universitas Airlangga; Jalan Airlangga No 4-6 Surabaya, 0315032770 \\ e-mail: tiarasosialita@psikologi.unair.ac.id
}

Received: $30^{\text {th }}$ September 2020/ Revised: $16^{\text {th }}$ December 2020/Accepted: $29^{\text {th }}$ December 2020

\begin{abstract}
This study was the continuance of the prior research of psychological intervention of patiens with type 2 diabetes mellitus. In this study, intervention was given to caregivers who caring of their family members in chronic illness. This consideration was chosen based on many feedbacks from community and health care personnels. This research was conducted as a solution to help caregivers of chronic illness deal with their stressful situation. Caregivers are required to care their family members optimally eventhough they are also vulnerable to stress. Based on this condition, the purpose of this research is to test the effectiveness of stress management to reduce stress level in 20 caregivers used experimental design, one group pretest-posttest design. Data collection used Perceived Stress Scale (PSS) questionnaire by Cohen. Data analysis used paired sample t-test with SPSS 20 showed that there was a significant difference of stress level between before and after stress management intervention. The result revealed that stress management is effective for reducing stress in caregivers.
\end{abstract}

Keywords: Caregiver; chronic illness; stress management

\begin{abstract}
Abstrak. Penelitian ini dilakukan sebagai salah satu solusi untuk mengatasi stres yang dialami oleh caregiver penyakit kronis berdasarkan keluhan awal dari keluarga dan tenaga kesehatan di Puskesmas. Adanya permasalahan bahwa kondisi caregiver rentan mengalami stres, akan tetapi mereka dituntut keadaan untuk merawat anggota keluarganya secara optimal. Berdasarkan hal tersebut, tujuan penelitian ini adalah menguji efektivitas manajemen stres untuk menurunkan tingkat stres pada caregiver penyakit kronis dengan menggunakan desain eksperimen one group pretest-posttest design pada 20 orang caregiver penyakit kronis yang ditentukan dengan metode purposive random sampling. Instrumen pengambilan data menggunakan kuesioner skala Perceived Stress Scale (PSS) dari Cohen. Analisis data menggunakan paired sample t-test dengan software SPSS 20 menunjukkan bahwa terdapat perbedaan yang signifikan antara tingkat stres sebelum dan sesudah pemberian intervensi manajemen stres. Hasil penelitian mengungkapkan bahwa manajemen stres yang diberikan efektif untuk menurunkan stres pada caregiver penyakit kronis.
\end{abstract}

Kata kunci: Caregiver; manajemen stres; penyakit kronis

Penyakit kronis yang semakin

meningkat prevalensinya secara global telah ditetapkan sebagai salah satu epidemi kesehatan di masyarakat. WHO menjabarkan bahwa penyakit kronis merupakan penyakit jangka panjang 
dengan progresivitas yang lama, diantaranya seperti penyakit jantung, stroke, kanker, penyakit pernapasan kronis, depresi, dan diabetes (WHO, 2020). Fakta dari National Health Council pada tahun 2014 mengungkapkan bahwa 133 juta warga Amerika atau lebih dari $40 \%$ dari total penduduk Amerika menderita sakit kronis. Hal tersebut juga terjadi di Eropa dengan prevalensi peningkatan penyakit kronis sebesar 6,3\% pada lakilaki dan $8 \%$ pada perempuan di kelompok usia dewasa (Cox \& GonderFrederick, 2012).

Prevalensi penyakit kronis di Indonesia pun mengalami peningkatan dalam dekade terakhir, bahkan beban penyakit kronis di Indonesia dapat berada pada ambang epidemi tanpa adanya kebijakan dan kontrol khusus (Depkes, 2019). Berdasarkan Riset Kesehatan Dasar tahun 2018, prevalensi penyakit kronis meningkat dari survei tahun 2013 dimana stroke pada usia $>15$ tahun (naik 56\%), diabetes mellitus (naik $23 \%$ ), hipertensi pada usia $>18$ tahun (naik 32\%), dan obesitas (naik 47\%) (Depkes, 2019).

Adanya fenomena bahwa prevalensi penyakit kronis semakin meningkat, membuat dampak yang ditimbulkan pada penderita dan keluarga pun perlu menjadi perhatian. Banyak penelitian terdahulu menunjukkan betapa penyakit kronis dapat memengaruhi semua aspek kehidupan pasien dan keluarga mereka (Duggleby, dkk., 2010). Penyakit kronis menyebabkan penderita mengalami penurunan kondisi fisik, sosial, dan psikologis setelah didiagnosa. Penderita menjadi kurang mampu hidup mandiri sehingga mengandalkan perawatan dari keluarga untuk menjaga dan meningkatkan kualitas hidup maupun kepatuhan pada pengobatan (Newby, dkk., 2011). Selain itu, penyakit kronis memerlukan pengobatan dan pengelolaan seumur hidup bagi penderita, sehingga menimbulkan dampak pada suasana hati, kebutuhan akan dukungan emosional dan fisik, serta finansial dapat menjadi beban bagi anggota keluarga yang merawat (Vieth, dkk., 2012).

Hal tersebut menunjukkan bahwa tidak hanya penderita yang rentan mengalami stres, namun keluarga sebagai caregiver juga rentan mengeluhkan gejala stres bahkan depresi. Beberapa penelitian pun 
mendukung temuan bahwa keluarga yang berperan sebagai caregiver rentan mengalami gangguan psikologis, seperti stres, cemas, suasana hati, maupun depresi (Foundation, 2015; Mada \& Pakenham, 2014; Sosialita, 2020). Senyatanya, peran caregiver sangat signifikan dalam membantu kesembuhan dan menentukan kualitas hidup penderita sakit kronis. Hal ini membuat kemampuan caregiver dalam melakukan fungsi sehari-hari merupakan faktor penting, namun sayangnya kondisi caregiver rentan mengalami stres, depresi, maupun kecemasan (Cox \& Gonder-Frederick, 2012; Duggleby, dkk., 2010).

Stres yang dialami oleh caregiver keluarga tidak hanya secara fisik, namun juga emosional karena menangani orang yang dikenal dan berarti dalam hidupnya (HearthMath, 2017). Mereka berisiko mengalami masalah emosional, mental, dan fisik akibat situasi yang dihadapi dan stres yang dialami dalam merawat anggota keluarga (Greenberg, 2017). Selain itu, rata-rata caregiver mengalami stres dan depresi ternyata $63 \%$ lebih tinggi daripada yang bukan caregiver (Martin, 2012). Hal senada juga dialami oleh keluarga pasien yang juga merangkap sebagai caregiver di wilayah kerja Puskesmas Medokan Ayu Surabaya. Rata-rata sebanyak 15.010 orang menderita sakit kronis seperti ISPA, jantung, hipertensi, stroke, diabetes mellitus dengan rentang usia 25-45 tahun.

Kondisi warga di daerah wilayah kerja Puskesmas Medokan Ayu ternyata menunjukkan bahwa rata-rata terdapat 130 warga yang menderita sakit kronis dalam satu keluarga, serta harus berobat tiap bulannya. Ibu-ibu rumah susun (rusun) Penjaringan Sari banyak yang harus merawat suami atau anggota keluarga mereka yang lain. Hal tersebut dirasa oleh ibu-ibu caregiver menambah beban pikiran mereka karena dituntut melakukan peran sebagai caregiver anggota keluarganya yang sakit kronis. Menjalankan peran sebagai caregiver dalam keluarga membuat kondisi mereka tidak seperti biasanya, seperti menjadi lebih mudah marah, sering murung, tidak nafsu makan sejak anggota keluarganya sakit, lebih sering mencemaskan keadaan anggota keluarga, maupun sakit kepala. Berdasarkan pengambilan data awal melalui observasi dan wawancara 
dengan para ibu caregiver tersebut, dapat diketahui bahwa tugas sebagai caregiver membuat kondisi fisik dan mental mereka rentan mengalami masalah.

Hal serupa juga diungkapkan oleh petugas Puskesmas yang menangani warga di wilayah tersebut, bahwa caregiver pasien penyakit kronis sering berobat dengan keluhan fisik dan psikologis disamping juga mengantar keluarga mereka berobat (Sosialita, 2019). Sebagaimana hasil pengambilan data awal, warga yang menjadi caregiver anggota keluarganya sering mengeluhkan stres atau cemas ketika keluarga mereka menderita sakit kronis sehingga mereka harus berperan sebagai caregiver. Ibu-ibu tersebut sering mengeluh stres, lelah, dan terkuras tenaga maupun pikiran karena merawat anggota keluarganya sehingga mengabaikan kesehatan diri sendiri. Menurut dokter Puskesmas, pengabaian terhadap kesehatan sendiri bahkan juga mengabaikan anggota keluarga yang seharusnya dirawat, dapat terjadi akibat memuncaknya stres tanpa dikelola dengan tepat.

Stres yang tidak terkelola dengan baik akan menimbulkan kerugian bagi pasien maupun caregiver sendiri. Hal ini sebenarnya bisa terjadi karena terbatasnya pengetahuan mengenai stres dan cara mengelola stres secara tepat. Menurut Bright Focus Foundation (2015), salah satu cara agar peran sebagai caregiver dapat berjalan dengan efektif adalah melakukan manajemen stres untuk mengelola stres yang dirasakan secara tepat. Salah satu faktor penting bagi caregiver adalah pengetahuan mengenai stres dan cara untuk menanganinya sehingga peran mereka sebagai caregiver dapat berjalan dengan baik.

Penelitian dari Pattison dan Lee (2011), Lupien (2012), Mada dan Pakenham (2014), serta Greenberg (2017) mengungkap bahwa terdapat korelasi positif antara manajemen stres dengan kualitas caregiver dalam menghadapi tuntutan peran dan mengatasi stres yang dirasakan. Semakin mampu caregiver menerapkan manajemen stres, maka semakin efektif mereka menjaga kesehatan pasien maupun diri sendiri (Pattison \& Lee, 2011). Caregiver yang dapat menerapkan manajemen stres dengan efektif, akan mampu menurunkan tingkat stres yang mereka rasakan sehari-hari sehingga 
aktivitas mereka pun dapat dilakukan secara optimal (Greenberg, 2017; Lupien, 2012; Mada \& Pakenham, 2014).

Manajemen stres merupakan kemampuan untuk mengendalikan diri ketika menghadapi situasi, orang-orang, dan kejadian-kejadian yang memberikan tuntutan atau tekanan berlebihan (Greenberg, 2017; Lupien, 2012; Mada \& Pakenham, 2014). Berdasarkan sudut pandang psikologi, manajemen stres merupakan strategi coping stres dimana individu mencoba untuk mengelola antara tuntunan (baik yang berasal dari diri ataupun lingkungan) menggunakkan sumber daya yang dimiliki guna menghadapi situasi yang menimbulkan stres (Greenberg, 2017; Lupien, 2012; Mada \& Pakenham, 2014). Keterampilan manajemen stres mencegah munculnya stres dengan meningkatkan ambang batas stres individu dan mengelola akibat fisiologis yang ditimbulkan stres tersebut (Greenberg, 2017; Lupien, 2012; Mada \& Pakenham, 2014).

Manajemen stres dalam penelitian ini memberikan keterampilan khusus bagi caregiver untuk mengelola pikiran, emosi, dan situasi eksternal. Selain itu, permasalahan-permasalahan yang khas dialami oleh caregiver juga dibahas dan dicari solusinya. Tujuan utama manajemen stres ini memberikan keterampilan bagi caregiver untuk mengelola stres dengan cara mengendalikan diri, mengelola jarak dengan situasi yang menekan, memanfaatkan sumber daya dengan produktif, serta meningkatkan ambang stres akibat fisiologis yang muncul.

Melihat dari fenomena yang ada tersebut, maka dapat dikatakan bahwa terdapat permasalahan pada ibu-ibu yang menjadi caregiver bagi anggota keluarganya yang sakit kronis, yaitu keluhan gejala stres yang dirasakan namun pengetahuan mereka megenai stres tergolong kurang. Dengan demikian, adanya manajemen stres bagi ibu-ibu yang berperan sebagai caregiver merupakan kebutuhan yang perlu dikuasai sehingga mereka memiliki pemahaman mengenai stres dan cara mengatasinya dengan tepat. Adanya manajemen stres diperlukan bagi caregiver agar mereka memiliki pengetahuan mengenai stres dan mampu mempraktikkannya jika merasakan gejala. Dengan demikian, penelitian ini diharapkan mampu menjadi solusi atas permasalahan dan 
kebutuhan para caregiver dalam mengatasi stres.

\section{Metode}

\section{Partisipan Penelitian}

Subjek penelitian merupakan 20 orang ibu-ibu di Rusun Penjaringan Sari yang menjalani peran sebagai caregiver anggota keluarganya. Kriteria subjek penelitian tersebut berdasarkan hasil wawancara dengan dokter, perawat, petugas Puskesmas, kader maupun warga rusun Penjaringan Sari. Selain dari hasil wawancara, pertimbangan terkait subjek penelitian juga berdasarkan hasil observasi terhadap kondisi keseharian warga rusun.

Pertimbangan tersebut juga didasarkan atas urgensi pentingnya mengajarkan pengetahuan mengenai stres dan cara memanajemen stres bagi warga yang menjalankan peran sebagai caregiver karena rentan berdampak pada kesehatan fisik maupun mental orang yang dirawat maupun mereka sendiri. Adanya tuntutan sebagai caregiver menyebabkan potensi yang besar untuk mengalami stres.

Selain itu, pertimbangan dari sisi Puskemas sendiri pun mengungkapkan bahwa ibu-ibu rusun perlu untuk diberikan pengetahuan dan keterampilan manajemen stres karena selama ini informasi mengenai hal tersebut kurang. Pertimbangan-pertimbangan tersebut menjadi dasar dalam penetapan subjek penelitian dalam penelitian ini. Adapun kriteria subjek penelitian adalah sebagai berikut :

1. Merupakan caregiver dengan anggota keluarga yang sakit kronis

Tingkat stres yang dialami ooleh caregiver tergantung pada keseriusan dan keparahan penyakit pasien yang harus mereka rawat (Sosialita, 2019). Mempertimbangkan hal tersebut, maka pemilihan partisipan diarahkan pada caregiver penyakit kronis karena mereka harus merawat pasien yang memiliki tuntutan tertentu, pantangan, maupun rutinitas yang harus dipatuhi seumur hidup.

2. Berjenis kelamin perempuan dan sudah menikah

Adanya tuntutan dan peran ganda yang dijalankan oleh perempuan di daerah tempat penelitian yaitu selain sebagai istri, juga bekerja baik swasta maupun wiraswasta. Hal ini rentan menyebabkan kondisi yang menimbulkan stres lebih tinggi.

3. Usia $25-50$ tahun 
Penetapan rentang usia ini yang merupakan tipe penelitian tanpa mempertimbangkan konflik dan tugas perkembangan yang cukup kompleks, baik sebagai anggota keluarga maupun anggota masyarakat randomisasi dengan memilih subjek penelitian sesuai dengan kriteria yang ditentukan

Pengambilan data pretest

4. Pendidikan SMP-SMA

Peneliti membatasi pendidikan terakhir SMP atau SMA, pertimbangannya adalah paling tidak subjek penelitian memahami penjelasan yang diberikan dan mampu mengingat dengan memadai teknik-teknik manajemen stres untuk dipraktikkan ketika mereka merasa stres.

5. Memiliki skor stres dengan kategori sedang hingga tinggi yang diukur dengan skala PSS

6. Bersedia mengikuti intervensi manajemen stres selama jangka waktu tertentu

\section{Prosedur Penelitian}

Penelitian ini menggunakan desain eksperimen pretest-posttest one group design dengan tujuan mengukur efektivitas perlakuan (intervensi manajemen stres) terhadap tingkat stres pada caregiver dengan anggota keluarga yang mengalami sakit kronis, sebagai subjek penelitian. Penelitian ini menggunakan tipe kuasi eksperimen

\section{NOTICE AND EASETM}

Teknik yang direkomendasikan untuk dimulai pada proses awal karena mudah dipelajari dan dapat membantu menurunkan ketegangan secara praktis, yaitu teknik Notice and Ease ${ }^{\mathrm{TM}}$. Teknik ini didesain untuk membantu lebih santai dengan emosi yang membuat stres dan menghentikan timbunan emosi sebagai 
hasil dari stres karena merawat keluarga yang sakit (HeartMath, 2017).

\section{GO TO NEUTRAL}

Teknik ini bertujuan untuk membuat tempat netral dimana subjek merasa nyaman, tenang dan tidak memikirkan rasa khawatir, cemas, takut atau asumsi-asumsi mengganggu lainnya. Subjek dapat menggunakan teknik ini untuk mendapatkan kekuatan emosional. Neutral adalah sebuah tempat yang ada dalam diri dimana subjek dapat berbicara secara bijak dengan bagian dirinya yang terganggu (merasa cemas, takut, marah, jengkel, dan sebagainya) dan tumpukan emosi. Saat segala sesuatu terjadi secara cepat dan mengganggu, teknik "Go to Neutral" membantu subjek untuk berhenti sejenak dan tidak semakin menambahkan drama-drama kehidupan pada situasi yang terjadi.

Ketika subjek dalam keadaan netral, maka akan dapat merespon dengan lebih baik dan menyimpan energi (HearthMath, 2017).

\section{HEART LOCK-IN®}

Teknik ini didesain untuk membantu subjek agar dapat lebih seimbang. Selama mempraktikkan Heart Lock-In, subjek menemukan tempat untuk duduk dan mendapatkan energi positif dari apresiasi, perasaan sayang dan perhatian bagi dirinya sendiri dan figur yang berarti dalam hidup subjek selama beberapa menit. Kebanyakan teknik Heart Lock-In dapat dipraktikkan selama 5 menit, sekali atau dua kali seminggu dapat menenangkan kemarahan dan meredakan dampak stres yang dihadapi sehari-hari. Heart Lock-In juga membantu untuk fokus dan menghentikan kegiatan yang menguras energy (HeartMath, 2017).

\section{Instrumen Penelitian}

Peneliti menggunakan skala PSS dari Cohen yang sering digunakan sebagai alat asesmen untuk mengukur persepsi stres. Item-itemnya mengukur bagaimana respon stres individu ketika dihadapkan pada situasi yang tidak terprediksi, tidak terkontrol, maupun kejadian yang stressful. Item pertanyaan yang mudah dipahami, serta adanya respon alternatif yang mudah didapatkan menjadi pertimbangan bagi peneliti untuk menggunakan skala ini.

Item dalam PSS seputar perasaan dan pikiran yang dirasakan selama sebulan terakhir. Item-item PSS juga berkorelasi dengan status kesehatan sehingga sesuai dengan penelitian ini. Selain itu, PSS juga menunjukkan korelasi 
dengan stres yang ditimbulkan oleh kejadian sehari-hari, kejadian luar biasa dalam hidup, dan perubahan dalam strategi coping. Berikut blue print skala PSS:

\section{Tabel 1.}

Blue Print Perceived Stress Scale (PSS)

\begin{tabular}{lccc}
\hline \multicolumn{1}{c}{ Dimensi } & $\begin{array}{c}\text { No Item } \\
\text { Favorable }\end{array}$ & $\begin{array}{c}\text { No Item } \\
\text { Unfavorable }\end{array}$ & Jumlah \\
\hline $\begin{array}{l}\text { Tak } \\
\text { terduga }\end{array}$ & 1 & 5 & 2 \\
$\begin{array}{l}\text { Tak } \\
\text { terkendali }\end{array}$ & $2,6,9$ & 4,7 & 5 \\
$\begin{array}{l}\text { Beban } \\
\text { dalam }\end{array}$ & 3,10 & 8 & 3 \\
hidup & & & \\
Total & & & 10 \\
\hline
\end{tabular}

Dasar kategorisasi stres digolongkan berdasarkan lima (5) standar penilaian (sten-five), yaitu: tinggi sekali, tinggi, sedang, rendah, rendah sekali.

Skala stres yang digunakan dalam penelitian ini merupakan adaptasi dari Bahasa Inggris. Peneliti meminta professional judgment dari profesional di bidang bahasa dan psikologi. Skala adaptasi mengalami perbaikan sehingga peneliti melakukan uji coba skala stres pada 45 orang dengan karakteristik sesuai dengan subjek penelitian. Data uji coba kemudian dianalisis validitas dan reliabilitas dengan SPSS 20. Hasil uji validitas skala stres didapatkan nilai rit dengan rentang 0.681-0.888 sehingga setiap item pada alat ukur ini dinyatakan valid. Sedangkan dari hasil uji reliabilitas menunjukkan bahwa skala stres yang digunakan dalam penelitian ini, yaitu adaptasi dari PSS (Perceived Stress Scale) menunjukkan hasil Cronbach Alpha = 0.836. Dengan demikian kesepuluh item kuesioner dinyatakan reliabel dalam mengukur level stres.

\section{Analisis Data \\ Skala pada penelitian ini} digunakan untuk membandingkan skor sesudah dan sebelum intervensi manajemen stres, sehingga dapat diketahui efektivitasnya. Peneliti juga melakukan uji normalitas dan homogenitas data. Hasil intervensi dapat dilihat melalui uji beda sebelum dan sesudah perlakuan dengan membandingkan gain score pada masingmasing periode pengambilan data pretest dan posttest. Teknik analisa data yang digunakan adalah paired sample t-test.

Selain itu, hasil dari uji statistik yang diperoleh juga digunakan untuk mengetahui tingkat efektivitas dari terapi yang diberikan terhadap perubahan nilai variabel terikat sebelum dan sesudah perlakuan. 
Adapun seluruh pengujian hipotesis pada penelitian ini akan menggunakan software SPSS 20.0 for Windows. Perhitungan effect size dilakukan dengan perhitungan secara manual dengan rumus perhitungan nilai effect size.

\section{H a s i 1}

Partisipan penelitian terpilih berdasarkan screening yang dilakukan sesuai dengan kriteria, yaitu: ibu-ibu di daerah Penjaringan Sari yang memiliki anggota keluarga serumah menderita penyakit kronis, berperan sebagai caregiver, serta mengalami stres dengan level sedang hingga tinggi berdasarkan skala PSS (Perceived Stress Scale). Deskripsi subjek penelitian sesuai dengan kriteria yang telah ditetapkan oleh peneliti dapat dilihat pada tabel 2 .

\section{Tabel 2.}

Deskripsi Data Skor Stres

\begin{tabular}{llcccl}
\hline No & Nama & $\begin{array}{c}\text { Usia } \\
\text { (tahun) }\end{array}$ & Pendidikan & Alamat & \multicolumn{1}{c}{ Caregiver } \\
\hline 1 & UKS & 29 & SMK & D-A/411 & Orangtua: DM \\
2 & S & 56 & SMP & A/304 & Suami: TB \\
3 & P & 56 & SMP & C/318 & Suami: Hipertensi, stroke \\
4 & ES & 55 & SMP & D-B/214 & Suami: Hepatitis B \\
5 & M & 50 & SD & B/316 & Suami: DM \\
6 & S & 46 & SD & C/209 & Suami: Hipertensi \\
7 & ATW & 36 & SMEA & B/116 & Suami: DM \\
8 & I & 50 & SD & F-B/304 & Suami: Hipertensi \\
9 & Rr. & 57 & Tidak & B/112 & Suami: Diabetes \\
& IMM & & Sekolah & & Cucu: Radang otak \\
10 & S & 58 & SD & E-B/309 & Suami: stroke \\
11 & M & 45 & SMA & F-A/209 & Suami: Ginjal \\
12 & R & 46 & SMA & F-A/204 & Suami: ISPA \\
13 & M & 42 & SMA & E-A/312 & Suami: Hipertensi \\
14 & M & 36 & SMK & E-B/311 & Orangtua: DM, hipertensi \\
15 & RC & 35 & SMA & F-A/208 & Ibu dan anak: ISPA \\
16 & S & 35 & SD & F-B/302 & Suami: DM \\
17 & PL & 35 & SLTP & F-B/305 & Orangtua: ISPA \\
18 & UJ & 37 & SLTP & A/313 & Suami: Hepatitis A \\
19 & M & 47 & SD & D-B/206 & Suami: Hipertensi \\
20 & RS & 57 & SMA & C/313 & Suami: DM \\
\hline
\end{tabular}

Hasil evaluasi analisis statistik

terhadap pengolahan data diperoleh dari data pretest dan posttest melalui pengisian kuesioner secara langsung oleh subjek penelitian. Sesuai dengan desain penelitian, maka cara untuk menganalisis data yang telah diperoleh adalah dengan melihat skor pretest, posttest, dan gain score antara sebelum dan sesudah intervensi. Hasil dari skor pretest dan posttest untuk masing-masing subjek dapat dilihat pada Tabel 3. 
Tabel 3.

Deskripsi Data Skor Stres

\begin{tabular}{|c|c|c|c|c|c|c|}
\hline Nama & $\begin{array}{c}\text { Skor } \\
\text { Pretest }\end{array}$ & Kategori & $\begin{array}{c}\text { Skor } \\
\text { Posttest }\end{array}$ & Kategori & $\begin{array}{l}\text { Gain } \\
\text { Score }\end{array}$ & Keterangan \\
\hline $\mathrm{MN}$ & 19 & Sedang & 14 & Rendah Sekali & 5 & Turun \\
\hline SU & 20 & Sedang & 19 & Sedang & 1 & $\begin{array}{c}\text { Turun, kategori } \\
\text { tetap }\end{array}$ \\
\hline PU & 19 & Sedang & 18 & Rendah & 1 & Turun \\
\hline I & 21 & Tinggi & 17 & Rendah & 4 & Turun \\
\hline $\mathrm{MO}$ & 24 & Tinggi Sekali & 18 & Rendah & 6 & Turun \\
\hline MI & 19 & Sedang & 17 & Rendah & 2 & Turun \\
\hline $\mathrm{R}$ & 20 & Sedang & 15 & Rendah Sekali & 5 & Turun \\
\hline ESW & 23 & Tinggi & 19 & Sedang & 4 & Turun \\
\hline RS & 19 & Sedang & 14 & Rendah Sekali & 5 & Turun \\
\hline $\mathrm{SH}$ & 23 & Tinggi & 20 & Sedang & 3 & Turun \\
\hline $\mathrm{TI}$ & 22 & Tinggi & 21 & Tinggi & 1 & $\begin{array}{c}\text { Turun, kategori } \\
\text { tetap }\end{array}$ \\
\hline MA & 19 & Sedang & 17 & Rendah & 2 & Turun \\
\hline $\mathrm{P}$ & 20 & Sedang & 15 & Rendah Sekali & 5 & Turun \\
\hline $\mathrm{RC}$ & 19 & Sedang & 18 & Rendah & 1 & Turun \\
\hline MU & 26 & Tinggi Sekali & 21 & Tinggi & 5 & Turun \\
\hline UKS & 19 & Sedang & 18 & Rendah & 1 & Turun \\
\hline IS & 20 & Sedang & 17 & Rendah & 3 & Turun \\
\hline M & 21 & Tinggi & 20 & Sedang & 1 & Turun \\
\hline$S$ & 22 & Tinggi & 19 & Sedang & 3 & Turun \\
\hline ATW & 19 & Sedang & 18 & Rendah & 1 & Turun \\
\hline
\end{tabular}

Data penelitian kemudian dianalisis normalitasnya menggunakan uji Kolmogorov-Smirnov dengan software SPSS 20 for Windows. Berdasarkan hasil uji normalitas yang telah dilakukan, distribusi data pada skala stres adalah normal dengan nilai signifikansi 0,305. Hasil uji normalitas dapat dilihat pada tabel 4 .
Tabel 4.

Hasil Uji Normalitas Stres Subjek Penelitian

\begin{tabular}{lcc}
\hline & $\begin{array}{l}\text { Kolmogorof } \\
\text { Smirnov } \\
\text { Asymp.Sig. } \\
\text { (2-tailed) }\end{array}$ & Keterangan \\
\hline $\begin{array}{c}\text { Gain Score } \\
\text { Stres }\end{array}$ & 0,305 & $\begin{array}{c}\text { Distribusi data } \\
\text { normal }\end{array}$ \\
\hline Selain $\quad$ uji & normalitas, uji \\
homogenitas juga dilakukan untuk \\
mengetahui varian data yang diperoleh \\
bersifat homogen atau heterogen.
\end{tabular}


Uji homogenitas dilakukan dengan teknik Levene menggunakan software SPSS 20 for Windows. Berdasarkan hasil uji homogenitas, ditemukan bahwa nilai signifikansi gain score stres bersifat homogen dengan nilai 0,322. Hasil uji homogenitas dapat dilihat pada tabel 5 .

\section{Tabel 5.}

Hasil Uji Homogenitas Stres Subjek

Penelitian

\begin{tabular}{clc}
\hline & $\begin{array}{l}\text { Levene's Test } \\
\text { Signifikansi }\end{array}$ & Keterangan \\
\hline Gain & 0,322 & Varian data \\
Score & & homogen \\
Stres & & \\
\hline
\end{tabular}

Berdasarkan uji normalitas dan homogenitas yang telah dilakukan, menunjukkan bahwa data berdistribusi normal dan homogen sehingga dapat diuji dengan statistik parametrik. Langkah berikutnya adalah melakukan uji beda pada sebelum dan sesudah pemberian perlakuan dengan menggunakan paired sample t-test melalui software SPSS 20 for Windows. Nilai signifikansi pada gain score stres pada kelompok subjek penelitian untuk sebelum dan sesudah perlakuan sebesar 0,028. Kesimpulan yang dapat ditarik adalah terdapat perbedaan antara sebelum dan sesudah diberikannya manajemen stres. Hasil analisis uji beda pada subjek penelitian sebelum dan sesudah perlakuan dapat dilihat pada tabel 6.

\section{Tabel 6.}

Hasil Uji Beda Antara Sebelum dan Sesudah Pemberian Perlakuan

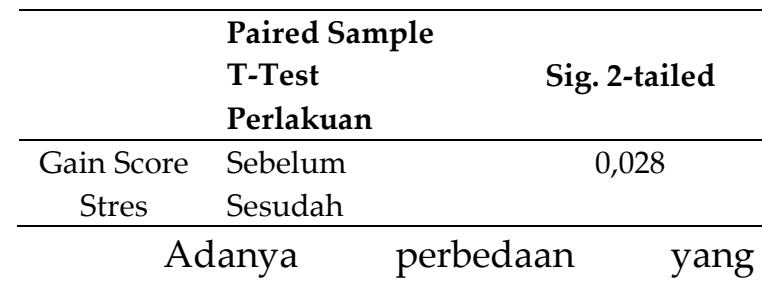
signifikan pada skor stres sebelum dan sesudah pemberian manajemen stres, menunjukkan bahwa perlakuan yang diberikan menyebabkan perubahan pada tingkat stres subjek penelitian. Dengan demikian, kemudian dilakukan uji efektivitas untuk mengetahui seberapa efektif manajemen stres dapat menurunkan stres pada subjek penelitian. Perhitungan nilai effect size (ES) pada kelompok subjek penelitian dilakukan dengan perhitungan manual.

Hasil perhitungan effect size menunjukkan bahwa manajemen stres yang diberikan tergolong efektif, yaitu sebesar 1,83. Dengan demikian, dalam penelitian ini dapat dikatakan bahwa manajemen stres memiliki efektivitas yang tergolong besar untuk menurunkan stres pada caregiver yang berada di daerah Penjaringan Sari. Hasil perhitungan effect size dapat dilihat pada tabel 7. 
Tabel 7.

Efektivitas Manajemen Stres

\begin{tabular}{ccccccc}
\hline & $\begin{array}{c}\text { Mean } \\
\text { Pretest }\end{array}$ & SD Pretest & $\begin{array}{c}\text { Mean } \\
\text { Posttest }\end{array}$ & SD Posttest & Nilai ES & Kategori \\
\hline Stres & 20,5 & 3,281 & 25,1 & 3,742 & 1,83 & $\begin{array}{c}\text { Efektivitas } \\
\text { Besar }\end{array}$ \\
\hline
\end{tabular}

Diskusi

Hasil penelitian dan hasil evaluasi pelaksanaan menunjukkan bahwa subjek penelitian menjadi memiliki pengetahuan yang lebih mengenai stres dan cara mengatasinya. Mereka menjadi lebih mampu menerapkan strategi dan caracara yang dipraktikkan ketika merasa stres dengan kondisi sehari-hari terkait bertambahnya beban karena merawat anggota keluarga yang sakit kronis. Mereka dapat memahami bahwa stres dapat timbul karena kurangnya keterampilan dalam mengelola stres yang dirasakan.

Partisipan penelitian menilai bahwa mereka mendapat manfaat dengan mempratikkan keterampilan manajemen stres yaitu mampu mengurangi stres yang dirasakan. Hal ini sesuai dengan tipe individu yang berusaha lebih terbuka terhadap informasi baru sebagai usaha dalam melakukan peran sebagai caregiver ketika mengatasi hambatan-hambatan yang dialami (Martin, 2012).

Kurangnya pengetahuan dan keterampilan manajemen stres subjek penelitian disebabkan karena terbatasnya pengetahuan mereka mengenai stres, sehingga stres yang mereka rasakan tidak tertangani dengan tepat dan malah semakin mengganggu. Sesuai dengan penelitian Li, dkk. (2017) yang juga menyampaikan bahwa ketidakmampuan caregiver menjalankan peran bagi anggota keluarga yang sakit dapat dialami oleh masyarakat dengan status ekonomi menengah ke bawah dan pendidikan yang kurang, disebabkan terbatasnya akses pada pengetahuan. Manajemen stres dengan metode yang telah disesuaikan karakteristik subjek penelitian, menunjukkan bahwa subjek penelitian memiliki pengetahuan dan keterampilan manajemen stres yang sebelumnya belum mereka kuasai.

Hasil dari intervesi yang diberikan juga menunjukkan bahwa keterampilan manajemen stres yang dimiliki oleh subjek penelitian mampu mengurangi tingkat stres mereka. Hasil pretest dan posttest menunjukkan adanya perbedaan tingkat stres yang signifikan antara sebelum dan sesudah intervensi, yaitu 
nilai signifikansinya 0,028 . Partisipan penelitian mengungkapkan bahwa mereka mampu lebih memanajemen diri sendiri ketika mengalami stres melalui praktik strategi manajemen stres yang efektif. Hal ini dapat disebabkan karena subjek penelitian telah mendapatkan strategi keterampilan manajemen stres yang dipraktikkan ketika mereka merasa stres, sedangkan sebelumnya mereka cenderung merespon stres dengan mengabaikan atau melampiaskan tekanan yang dirasakan (Sosialita, 2019; Greenberg, 2017).

Peran sebagai caregiver yang kurang optimal juga disebabkan oleh tekanan ketika merawat anggota keluarga mereka. Hanya saja, respon yang mereka tunjukkan cenderung kurang efektif dalam menghadapi stres sehingga tindakan mereka menjadi merugikan diri sendiri maupun keluarga. Hal ini sesuai dengan temuan bahwa caregiver rentan mengabaikan kesehatan diri sendiri, serta memiliki risiko pada masalah emosional, mental, dan kesehatan fisik (Sosialita, 2020; Olandirin, dkk., 2014). Risiko utama tampak lebih besar pada caregiver yang merawat anggota keluarganya, sehingga ketika mereka mampu menerapkan keterampilan manajemen stres maka mereka akan dapat menjalankan peran sebagai caregiver tanpa melupakan kesehatan mereka juga.

Pada penelitian ini, hasil dari manajemen stres yang diberikan tergolong efektif untuk menurunkan stres pada caregiver yang berada di daerah Penjaringan Sari dengan karakteristik yang juga khas secara sosio demografis. Hal ini menurut peneliti, menyebabkan hasil dari penelitian ini perlu diuji kembali ketika diterapkan pada populasi yang berbeda. Oleh karenanya, tahap pemetaan subjek penelitian merupakan salah satu tahapan terpenting untuk mengetahui gambaran permasalahan dan karakteristik populasi secara spesifik. Kejelasan dan kedetilan deskripsi pemetaan subjek menjadi unsur fundamental dalam mendesain sesi dan aktivitas manajemen stres yang tepat sasaran. Berdasarkan hasil penelitian ini, kesesuain desain intervensi yang diberikan dengan karakteristik populasi menjadi salah satu poin penting dalam keberhasilan intervensi.

\section{Kesimpulan}

Kesimpulan dari penelitian ini adalah manajemen stres yang diberikan efektif menurunkan stres pada caregiver 
dari pasien penyakit kronis, melalui pemberian psikoedukasi dan penerapan teknik-teknik manajemen stres. Adanya peningkatan pengetahuan mengenai stres dan manajemen stres membuat caregiver mengerti pentingnya mengelola stres sehingga mereka dapat menjalankan peran dengan efektif. Selain itu, keterampilan manajemen stres yang dipelajari juga membantu caregiver mengatasi tekanan yang dialami sehingga tingkat stres yang dirasakan dapat berkurang

Saran teoritis: Manajemen stres dengan teknik HeartMath dalam penelitian ini secara khusus memasukkan juga sesi pemberian materi, penugasan, dan aktivitas yang berfokus pada stres para caregiver. Hal ini terbukti efektif, sehinga saran untuk penelitian selanjutnya dapat menggunakan intervensi yang sama pada sampel yang berbeda untuk membuktikan efektivitas manajemen stres dengan teknik HeartMath dalam menurunkan stres pada berbagai sasaran.

Saran praktis: Saran yang dapat diberikan bagi caregiver anggota keluarga yang sakit kronis adalah hendaknya membentuk dukungan sosial satu sama lain, sehingga ilmu yang telah didapatkan dapat dipraktikkan secara konsisten. Adanya dukungan sosial juga memungkinkan caregiver di lingkungan Penjaringan Sari saling mengingatkan satu sama lain untuk melakukan manajemen stres ketika merasa beban fisik maupun psikis semakin bertambah. Selain itu, caregiver yang telah mendapatkan intervensi juga diharapkan mampu berbagi pengetahuan dan keterampilan kepada keluarga, teman, maupun tetangga.

\section{Daftar Pustaka}

Cox, D.J., \& Gonder-Frederick, L. (2012). Major developments in behavioral diabetes research. Journal of Consulting and Clinical Psychology, 60, 628-638.

Depkes. (2019). Diabetes mellitus dapat dicegah. Diakses pada tanggal 11 Desember 2019 dari www.depkes.go.id.

Duggleby, W., Holtslander, L., Kylma, J., Hammond, C., \& Williams, A. (2010). Metasynthesis of the hope experience of family caregivers of persons with chronic illness. Qualitative Health Research, 20, 148-158.

Foundation, B. F. (2015). Managing stress: Care for the caregiver. Clarksburg: Bright Focus Foundation.

Greenberg, J. S. (2011). Comprehensive stress management 12th edition. New York: McGraw-Hill Inc.

Greenberg, M. (2017). The stress-proof: Master your emotional response to stress using mindfulness \& neuroplasticity. Oakland: New Harbinger Publications, Inc.

HeartMath. (2017). Family caregiver's guide 
to coping with stress. Washington, DC: HeartMath, LLC.

Li, J., Riedel, N., Barrech, A., Herr, R. M., Aust, B., Mörtl, K., Siegrist, J., Gündel, H., \& Angerer, P. (2017). Long-term effectiveness of a stress management intervention at work: A 9-year follow-up study based on a randomized wait-list controlled trial in male managers. BioMed Research International, $\quad 1, \quad 24-35$. https://doi.org/10.1155/2017/2853813

Lupien, S. (2012). Well stressed: Manage stress before it turns toxic. Ontario: John Wiley \& Sons Canada, Ltd. https://doi.org/10.1017/CBO97811074 15324.004

Mada, S., \& Pakenham, K. I. (2014). The stress-buffering effects of hope on adjustment to multiple sclerosis. Journal of Behavioral \& Medical, 21, 877-890.

Martin, G. G. (2012). Stress management for social workers.

Newby, K., Bayley, J., \& Wallace, L. M. (2011). Coping with chronic illness for caregiver. Journal of Health Promotion Practice, 12, 209-228.

Oladinrin, T.O., Adeniyi, O., \& Udi, M.O. (2014). Analysis of stress management among professionals in the Nigerian construction industry. International Journal of Religious Health, 50, 731-742.
Pattison, N.A., \& Lee, C. (2011). Hope against hope in cancer at the end of life. Journal of Religious Health, 50, 731-742.

Sosialita, T. D. (2019). Hope-based intervention untuk menurunkan stres serta meningkatkan harapan dan subjective well-being pada penderita diabetes mellitus tipe 2 . Psikoislamika, 12(1), 55-63.

Sosialita, T. D. (2020). Online Counseling to Improve Mental Health among Midwives. Proyeksi: Jurnal Psikologi, 14(2), 94-103. https://doi.org/http://dx.doi.org/10.30 659/jp.14.2.94-103

Vieth, A.Z., Hagglund, K.J., Clay, D.L., Frank, R.G., Thayer J.F., Johnson, J.C., \& Goldstein, D. E. (2012). The contribution of hope and affectivity to diabetes-related disability. An exploratory studi. Journal of Clinical Psychology in Medical Setting, 4, 6577.

WHO. (2020, Januari). Chronic illness task force. Diakses pada tanggal 08 Februari 2020 dari http://www.who.int/mediacentre/fac tsheets/fs311/en/.

WHO. (2020, Januari). Diabetes mellitus. Diakses pada tanggal 08 Februari $2020 \quad$ dari http://www.who.int/topics/diabetes/ en. 